\title{
An Analysis of Errors in English Essays Written by Thai Non-English Major Students
}

\author{
Prathomwat Suraprajit \\ Faculty of Management Sciences, Kasetsart University Sriracha Campus, Thailand
}

\begin{abstract}
Writing is one of the vital skills for EFL learners. However, they still face some difficulties while processing a task. The present study aimed to analyze the errors that occurred on sixty English essays made by Thai University non-English major students who enrolled in the fundamental English course. The Surface Strategy Taxonomy (Dulay, Burt, \& Krashen, 1982) was adopted to explore the errors of omission, addition, misformation, and misordering together with those that were excluded in the taxonomy. According to the framework of Surface Strategy Taxonomy, the findings revealed the most common errors involving omission of articles, followed by the addition of the preposition, the omission of the preposition, the omission of the subject, and misformation of subject pronoun, respectively. Then, according to the errors which were out of the stated taxonomy, the errors in subject-verb agreement were the highest detected error, followed by tense errors, ambiguous sentences, a direct translation from L1 to L2, misformation of object pronoun, misformation of using an adjective as the main verb, the addition of verb to be, and addition of conjunction, respectively. By investigating the errors in foreign language writing, the results would trigger foreign language learners to aware of the error of English writing that might occur. And the benefit also goes to the pedagogy in developing the teaching materials together with teaching strategies.
\end{abstract}

Index Terms - error analysis, Thai EFL learners, surface strategy taxonomy

\section{INTRODUCTION}

The English language plays a crucial role as a medium language for people around the world. It is used for various purposes such as business interaction and academic cooperation. For this reason, English is one of the most popular languages to be studied for learners worldwide. The importance of the English language has also spread to all Southeast Asian countries, especially on the time when the ASEAN Economic Community (AEC) was formed. Used as a global language for communicating in various fields, people in Southeast Asia use English for processing their interaction around the region. However, the English proficiency of people in each country around AEC is different due to the intensity of English usage in each country. For example, English is used as an official language or a recognized language in some member countries such as Singapore, Malaysia, Brunei Darussalam, and the Philippines. On the contrary, English is not used as the official language in Thailand, Cambodia, Indonesia, Myanmar, Vietnam, and Laos. Focusing on Thailand, having been taught in the nation since 1824 (Darasawang, 2007), most Thai students still struggle in achieving learning English. The evidence from the survey of Education First (Index, 2019) which reported the largest ranking of countries worldwide by English skills revealed that the proficiency in English skill of Thai students was low and very low proficiency during the last decades (2011-2019). Thus, all English skills have been increasingly required for Thai people (Kirkpatrick, 2012). Viewed as a foreign language, English has been instructed in Thai education by including four skills that are listening, speaking, reading, and writing. Among the stated skills, writing becomes more and more important for all students in various disciplines.

However, the writing skill has been determined one of the most difficult and complex skills that required more basic skills for foreign or second language learners to understand (Al-Shujairi \& Tan, 2017; Fareed, Ashraf, \& Bilal, 2016; Kirmizi \& Karci, 2017; Padgate, 2008; Sajid \& Siddiqui, 2015). Paying attention to Thai higher education, although there are many writing courses provided for Thai students, they still face some problems or difficulties in mastering the writing skill (Bennui, 2016; Boonyarattanasoontorn, 2017; Phuket \& Othman, 2015; Watcharapunyawong \& Usaha, 2013). Therefore, the stated issue may lead to a more critical situation when they graduate and move into the real working world. That is because their future employers always expect a good command in English from their prospective employees for communicating effectively a certain set of ideas. Focusing on writing skill, those who perform poor writing ability can imply a sign of a low performance, which results in having a little chance of getting promotion for management positions (Iamsiu, 2014). Then, the errors found in the writing tasks are the evidence from the difficulties in dealing with writing English for communication in the workplace. The study of error analysis then plays role in the field of language learning as it is the study of the process of language acquisition (Dulay et al., 1982; Ellis, 2002). It is crucial to study language learners' errors because the state of the learners' knowledge could be seen from this exploration (Brown, 2000; Corder, 1967). By knowing where to fix, the teacher could design the proper treatment for each student. In order to understand how and why these types of errors occur, research into error analysis (EA) should be conducted because its benefits are really obvious. Firstly, EA provides important information to the 
teacher as to "how far towards the goal the learner has progressed and, consequently, what remains for him to learn" together with providing insight into how second languages are learned and what phases learners go through in second language acquisition (Corder, 1967). Secondly, EA can help to investigate the language learning process and to guide the remedial actions teachers need to make in order to correct the errors for learners (Corder, 1981). Thirdly, EA can help to measure the language performance of learners (Dulay et al., 1982; Ellis, 2002) by detecting the proficiency level of students and obtaining information about the general difficulties in language learning. Fourthly, EA helps in identifying the development of learners, portraying conclusions to direct and adjusting the learning process (Ferris, 2011; Mitchell, Myles \& Marsden, 2019). Lastly, EA can improve the writing skill of learners as a measure of language learning success together with giving the opportunity to a teacher for establishing effective instructional strategies to enhance the writing skill of students (Waelateh, Boonsuk, Ambele, \& Jeharsae, 2019). The present study then argued that writing English was not an easy task for Thai EFL learners though they tried various learning strategies dealing with these difficult tasks. Thus, it was worth exploring the occurrences of errors found in English essay writings among Thai EFL learners in order that it could be an alternative to improve the English writing skill for them. The present study aimed to detect the two questions.

1) What are the errors under the Surface Strategy Taxonomy (Dulay et al., 1982) found in English essays written by Thai university non-English major students?

2) What are the errors excluded in the Surface Strategy Taxonomy of (Dulay et al., 1982) made by the same group?

\section{LITERATURE REVIEWS}

\section{A. Definitions of Error and Error Analysis (EA)}

Known as one of the very first founders of the field of error analysis, Corder defined error as the features of the learners' utterances that are different from those of any native speakers (Corder, 1973). Richards and Schmidt (2002) then defined error as the "use of a linguistic item (e.g. a word, a grammatical item, a speech act, etc.) in a way which a fluent or native speaker of the language regards as showing faulty or incomplete learning". The next definition of error was that it was an identifiable alteration of the grammatical elements of a native speaker, presenting the learners' competence in the target language (Brown, 2007). Another definition was that error was an integral and unavoidable feature of second language acquisition (Alanazi, 2017). Following the given definitions of error, error analysis was then very important for foreign language learning to clearly understand the process of the language (Jobeen, Kazemian, \& Shahbaz, 2015). Various definitions of error analysis were later shared by many scholars. Firstly, Dulay, Burt, \& Krashen (1982) defined EA as "a flawed side of learner speech or writing that deviates from the selected norm of mature language performance" (Dulay et al., 1982). Secondly, EA was defined as the study of unacceptable forms produced by someone learning a language, especially a foreign language (Crystal, 1999). Later, EA was described as the study and analysis of the errors made by second language learners (Richards \& Schmidt, 2013). Next, EA was described as a device to precisely measure the correctness consisting of a set of procedures for identifying, describing, and explaining learners' errors (Ellis \& Barkhuizen, 2005). In addition, EA was defined as a "red flag" which means they are warning signs that provide evidence of the learners' knowledge of the second language (Selinker \& Gass, 2008). The last definition which the present study noticed was that EA was as a comparison between "learner English" with English (L2) itself and judged how learners were ignorant (James, 2013).

\section{B. Classification of Errors}

As cited in Sompong (2013), Corder (1971) classified error into two types namely competence and performance. Firstly, the error of competence was divided into 1) interlingual which depended on linguistic differences between the mother language and the target language, and 2) intralingual which caused by overgeneralization in both the languages - mother language and the target language learning. Secondly, it was the error of performance. This type happened when learners' errors occurred due to stress, fatigue, and false starts or slips of the tongue (Sompong, 2013). Another classification of errors could be considered local and global errors (Burt \& Kiparsky, 1972). The local errors affected one element or constituent in a sentence which usually did not blend the meaning of the sentence, whereas the global errors affected the meaning of the whole sentence. Also, according to Dulay et al. (1982), error analysis was classified into four categories which were linguistic category classification, surface strategy taxonomy, comparative taxonomy, and communicative effect taxonomy. Among them, surface strategy taxonomy was the one that disclosed the types of errors the language learners made as well as leading them to unlock the factors beyond those errors (Imaniar, 2018).

\section{Framework}

The present study employed the Surface Strategy Taxonomy of Dulay, Burt, and Krashen (1982) to be a framework for investigating the errors in English essays written by Thai University students. There were many reasons why this taxonomy was selected. Firstly, it highlighted the way surface structures were altered (Dulay et al., 1982). It meant that students might apply the action of omitting, adding, misforming, and misordering during writing a sentence which might affect the semantic or syntactic of the sentence. Secondly, based on identifying cognitive processes that underlie the learners' reconstruction of the new language, this taxonomy could show that learners' error was not the result of careless or laziness, but was based on some logics which reflected the use of language among learners. Next, the 
taxonomy was appropriated for analyzing the written text. The evidence was that there were many previous studies (Imaniar, 2018; Kim \& Yoo, 2015; Maniam \& Rajagopal, 2016; Mustafa, Kirana, \& Bahri, 2017; Settanan, 2016; Sompong, 2013; Turtulla \& Lopar, 2018; and Zheng \& Park, 2013) which adopted the surface strategy taxonomy to explore the errors made by the non-native speakers. Then, the full detail of the taxonomy was presented in Table 1 .

TABLE 1

Surface Strategy TAXonomy Of DUlay, Burt, \& Krashen (1982)

\begin{tabular}{|c|c|}
\hline Classification & Example \\
\hline \multicolumn{2}{|l|}{ 1. Omission } \\
\hline \multicolumn{2}{|l|}{ 1.1 Omission of major constituents } \\
\hline 1.1.1 head noun & a dirty $\wedge$ \\
\hline 1.1.2 subject & $\wedge$ play football. \\
\hline 1.1.3 main verb & Tom $\wedge$ football. \\
\hline 1.1.4 direct object & He likes $\wedge$ \\
\hline \multicolumn{2}{|l|}{ 1.2 Omission of grammatical morphemes } \\
\hline 1.2.1 preposition: to, on, in & I fall down $\wedge$ the water. (in) \\
\hline 1.2.2 article: the, a & $\wedge$ cat goes there. \\
\hline 1.2.3 short plural: $-\mathrm{s}$ & It's got some flower $\wedge$. \\
\hline 1.2.4 auxiliary: do, does, did & $\mathrm{I} \wedge$ not/no hurt him. (do/did) \\
\hline 1.2.5 auxiliary: is, am, was & The car $\wedge$ coming. \\
\hline 1.2.6 copula: is, am & $\mathrm{I} \wedge$ sick. \\
\hline 1.2.7 progressive: -ing & A father is come. (coming) \\
\hline 1.2.8 regular past tense: - ed & He close it. (closed) \\
\hline 1.2.9 irregular past tense & Good beach fall down. (fell) \\
\hline 1.2.10 third person singular & It don't fit here. (doesn't) \\
\hline 1.2.11 infinitive marker: to & I don't like $\wedge$ eat. \\
\hline \multicolumn{2}{|l|}{ 2. Addition } \\
\hline \multicolumn{2}{|l|}{ 2.1 Double marking } \\
\hline 2.1.1 present indicative & Bill doesn't likes it carrots. \\
\hline 2.1.2 regular past & Why didn't you came to school? (come) \\
\hline 2.1.3 irregular past & Did I did it? / The bird stoled it. \\
\hline 2.1.4 direct object & Put it down card. / You don't get it the coffee. \\
\hline \multicolumn{2}{|l|}{ 2.2 Regularization } \\
\hline 2.2.1 regular plural: $(-\mathrm{s})$ & mouses \\
\hline 2.2.2 past tense marker: (-ed) & goed \\
\hline \multicolumn{2}{|l|}{ 2.3 Sample addition } \\
\hline 2.3.1 third person singular & The fishes doesn't live in the water. \\
\hline 2.3.2 preposition: in, to & You shop in over there. \\
\hline \multicolumn{2}{|l|}{ 3. Misformation } \\
\hline \multicolumn{2}{|l|}{ 3.1 Overregularization } \\
\hline 3.1.1 reflexive pronoun & He is licking hisself. (himself) \\
\hline 3.1.2 regular past & I falled. (fell) \\
\hline 3.1.3 third person singular & He gots a flower. (got) \\
\hline \multicolumn{2}{|l|}{ 3.2 Archi/Alternating forms } \\
\hline \multirow[t]{2}{*}{ 3.2.1 auxiliary: does/is } & What does he putting on the top? (is) \\
\hline & He don't looking. (is) \\
\hline 3.2.2 prepositions: at/to, on/in & Daddy took me at the train. (to) \\
\hline & in the feet. (on) \\
\hline \multirow[t]{2}{*}{ 3.2.3 subject pronoun: he/she } & Mommy was so mad so he spanked Backey. (she) \\
\hline & The mother's over there and he's nervous. (she's) \\
\hline \multirow[t]{2}{*}{ 3.2.4 Possessive pronoun: she, she's/her, him's/his } & That's she's house. (her) \\
\hline & She name is Maria. (Her) \\
\hline \multirow[t]{3}{*}{3.2 .5 negative: no/not } & Man no go in there. (not) \\
\hline & no going home. (not) \\
\hline & I no have it. (not) \\
\hline \multirow{2}{*}{ 3.2.6 quantifiers } & Puts a gas in. (some) \\
\hline & I see a teeth. (some) \\
\hline \multicolumn{2}{|l|}{ 4. Misordering } \\
\hline 4.1 aux in simple question & What this is? (What is this?) \\
\hline 4.2 aux in embedded question & I know what is that. (what that is) \\
\hline 4.3 adverb & I eat sometimes candy. (I eat candy sometimes) \\
\hline
\end{tabular}

\section{The Study of Error Analysis in Thailand}

To understand the direction of error analysis, it is necessary to review the studies related to EA which were widely conducted by Thai scholars in the last decade. The objectives of the previous studies conducted by Thai researchers were various e.g. searching for the types of errors (Iamsiu, 2014; Khumpee \& Yodkumlue, 2017; Kongkaew \& Cedar, 2018; Namkaew, 2015; Phuket \& Othman, 2015; Promsupa, Varasarin, \& Brudhiprabha, 2017; Sermsook, Liamnimit, \& Pochakorn, 2017; and Suvarnamani, 2017), investigating the source of errors (Phuket \& Othman, 2015; Promsupa et al., 2017; and Sermsook et al., 2017), or even examining the effects of L1 (Thai) interference (Bennui, 2016; Iamsiu, 
2014; Khumpee \& Yodkumlue, 2017; Rattanadilok Na Phuket \& Bidin, 2016; and Watcharapunyawong \& Usaha, 2013). Moreover, Thai scholars whose works related to EA still used various methods such as quantitative (Iamsiu, 2014; and Watcharapunyawong \& Usaha, 2013), qualitative (Kongkaew \& Cedar, 2018; Phuket \& Othman, 2015; and Suvarnamani, 2017), or even mixed-method (Namkaew, 2015; Promsupa et al., 2017; and Sermsook et al., 2017). Also, divided by the type of the writing tasks, there were those compiled the errors from the essays written by Thai students (Khumpee \& Yodkumlue, 2017; Phuket \& Othman, 2015; and Promsupa et al., 2017), online written tasks (Kongkaew \& Cedar, 2018), sentence writings (Sermsook et al., 2017), or even interview (Rattanadilok Na Phuket \& Bidin, 2016). Deeper details of the stated previous Thai studies on EA were presented as follows. Firstly, Iamsui (2014) investigated five types of errors in students' written works. The results appeared that the five types of errors caused by L1 interference including word choice errors, errors in sentence structure, subject-verb agreement, word order, and connecting word. Secondly, Phuket \& Othman (2015) explored the major sources of errors together with its types made by Thai EFL learners. The results revealed that the most frequent types of errors were translated words from Thai, word choice, verb tense, preposition, and comma, respectively. Khumpee \& Yodkumlue (2017) then investigated the common types of grammatical errors in English essays written by Thai EFL undergraduate students. The results showed that there were 26 types of grammatical errors, with the total number of 4,909 errors, occurred in the students' written works, and the five most common types of all were punctuation, nouns, prepositions, verbs, and articles, accordingly. Next, Sermsook, Liamnimit, \& Pochakorn (2017) explored the errors and their sources from 104 pieces of writing among Thai English major students. The findings showed that the most frequently committed errors were punctuation, articles, subject-verb agreement, spelling, capitalization, and fragment, respectively. Later, Promsupa, Varasarin, \& Brudhiprabha (2017) explored the grammatical error types and analyzed sources of the errors in English writing. The findings were that 2,218 grammatical errors were found in both of two main types: morphological errors $(81.97 \%)$ and syntactic errors (18.03\%). Finally, Suvarnamani (2017) investigated grammatical and lexical errors, particularly tense, fragment, and collocation errors, found in descriptive writing. The results were that 1) tense errors were identified and classified into 13 types, 2) there were 32 instances of fragment errors, 3) a total of 65 occurrences of collocation errors were found in the paragraphs of 51 students, 4) wrong pronunciation, lack of consistency and paying too much attention to content were main causes of the tense errors, 5) L1 interference was the main cause of the fragment errors and collocation errors resulted from the overuse of a direct translation method (Suvarnamani, 2017).

\section{METHODOLOGY}

\section{A. Participants and Materials}

The participants of the present study are thirty Thai university students aged between seventeen to eighteen years old majoring in computer engineering and informatics. They were recruited by using a convenience sampling method. They were those who enrolled in the fundamental English III course in the 2nd-semester academic year 2019 at a Thai public university. They all had the same level of English proficiency based on the score of the national English test that they took before entering the university for the academic year 2019. Then, the materials are the English essays written by the participants.

\section{B. Data Collection}

In each week, the participants were assigned to write one essay by mean that they could practice their writing by using the correct grammatical rules that they studied in each book chapter. The total that they composed were seven essays by including the grammatical features namely modifiers, active voice and passive voice, expressions of the contrastive ideas, causative verbs, adjective clauses and adverb clauses, reduction of adjective clauses and adverb clauses, and reported speech for each assignment. As the students were not informed that their writing assignments would be used to analyze for grammatical errors, their focus would be mainly on the grammatical feature of each chapter. Next, the last two essays were selected from each participant to be analyzed for the grammatical errors. The reason was that they had spent times practicing essay writing for five times which made them got used to with the essay writing. And, they also received some feedback for their first five essays. Finally, there appear sixty English essays retrieved from all participants.

\section{Data Analysis}

Supported by AntConc, the free access software with its multi-functions for various purposes (Anthony, 2005), the total words compiled from all sixty essays were 13521. And the average word of all sixty essays was 225.35 each. Next, error analysis was carried out in four consecutive stages (Ellis, 1994). These stages were that 1) collection of a sample of learner language, 2) identification of errors, 3) description of errors and 4) explanation of errors. The data analysis was then conducted base on the Surface Strategies Taxonomy (Dulay et al., 1982) as mentioned earlier.

\section{RESULTS AND DISCUSSION}


Thai University Non-English Major Students?

Table 2 presented the errors found under the Surface Strategy Taxonomy among Thai university students.

TABLE 2

THE RESUlts Under THE SURFACE STRATEgIES TAXONOMY

\begin{tabular}{|c|c|c|}
\hline Classification & No. of Frequency & Example \\
\hline 1. Omission of articles & 13 & I was like (a) dogs. \\
\hline 2. Addition of preposition & 11 & I ask to my father. \\
\hline 3. Omission of preposition & 8 & Parents ask what I want (to) study. \\
\hline 4. Omission of subject & 8 & because $\wedge$ will have fun. \\
\hline 5. Misformation of subject pronoun & 7 & Father asked if me (I) want to go. \\
\hline
\end{tabular}

According to table 2, the most frequent of errors were omission of articles (13), followed by the addition of a preposition (11), the omission of a preposition (8), the omission of a subject (8), and the misformation of a subject pronoun (7). There were some discussions on these findings. Firstly, Thai students omitted the use of the article the most. That is because the Thai language has no articles or is one of the article-free languages. Therefore, Thai students had a great deal of difficulty mastering the correct usage of articles in the target language (Nopjirapong, 2011). Secondly, the error in the use of preposition appeared on both omission and addition. It showed the significance of preposition in English writing among L2 learners. Presented a difficult challenge for all the levels of proficiency, the finding of the previous studies argued that the occurrence of errors in the use of prepositions was influenced by the speakers' first language (Suzanne, 2017; Thumawongsa, 2018) and these showed that the students failed to acquire competence in the lexicon of the English language (Pongpairoj, 2002). In contrast, many errors under the Surface Strategy Taxonomy were not found on the writing tasks of Thai learners e.g. misordering of auxiliary in a simple question, misformation of regular past and third-person singular, and omission of progressive, regular past tense, irregular past tense, third-person singular, head noun, accordingly.

B. What Are the Errors Excluded in the Surface Strategy Taxonomy (Dulay et al., 1982)Made by the Same Group?

Table 3 revealed the errors which were out of the frame of the Surface Strategy Taxonomy among Thai university students.

TABLE 3.

THE RESUlts IRRELEVANT To THE SURFACE STRATEGIES TAXONOMY

\begin{tabular}{|c|c|c|}
\hline Classification & No. of Frequency & Example \\
\hline 1. Subject Verb agreement & 28 & She like gardening. \\
\hline 2. Tense errors & 20 & I start over at KU last year. (started) \\
\hline 3. Ambiguous sentences & 18 & I believe me to success. (I believe I can succeed). \\
\hline 4. Direct translation: $\mathrm{L} 1$ to $\mathrm{L} 2$ & 14 & Then, I will finish university (graduate). \\
\hline 5. Misformation: Object pronoun & 13 & I advised they (them) not to get up late. \\
\hline 6. Misformation: Using adjective as & 9 & $\begin{array}{l}\text { it (is) hard to find a job. } \\
\text { a main verb }\end{array}$ \\
\hline 7. Addition: Verb to be & 7 & They are always support me \\
\hline 8. Addition: Conjunction & 6 & $\begin{array}{l}\text { Even though I have to exchange for sweat but it is } \\
\text { worthwhile. }\end{array}$ \\
\hline
\end{tabular}

According to table 3, declared as a common error among Thai learners (Iamsiu, 2014; Phuket \& Othman, 2015; Sermsook et al., 2017; Watcharapunyawong \& Usaha, 2013), error in subject-verb agreement was the most frequently found on the writing tasks of the present study. The reasons for the occurrence of this type of error might be rooted in the interlingual error, ignorance of rule restrictions, incomplete application of rules, false concepts hypothesized, and carelessness (Mali \& Yulia, 2017). Another highly found error was tense errors. These results were in the same line as some previous studies (Phuket \& Othman, 2015; Watcharapunyawong \& Usaha, 2013). It was argued that the cause of this error type might be that L1 syntactic properties were transferred in L2 writing (Watcharapunyawong \& Usaha, 2013). In the other words, the mother tongue interfered with the student's L2 writing, which eventually reduced his/her writing effectiveness. The third most found error was an ambiguous sentence. This error type might be caused by the lack of or limit of semantic competence of English words among Thai students (Tuaycharoen, 2003) together with the semantic errors (Sermsook et al., 2017). The fourth detected error was the direct translation from L1 to L2. Acting as a source of error (Khumpee \& Yodkumlue, 2017; Phuket \& Othman, 2015; Sermsook et al., 2017; Suvarnamani, 2017), this result was in the same line with those found in the previous studies (Iamsiu, 2014; Promsupa et al., 2017). Moreover, misformation in the subject pronoun was another error that should be discussed. The acquisition of English pronoun was a challenge for Thai learners, especially as English and their L1 (Thai) differed in morphosyntactically in an object pronoun. In morphosyntax, English pronouns appeared differently for a subject pronoun and an object 
pronoun, whereas the L1 (Thai) in this study showed no difference between both of them. Next, it was a discussion on misformation in using an adjective as a main verb. This error might be inspired by the reason that the L2 writers got used to with their L1 (Thai) form which did not require an auxiliary verb when adding some related meanings to the nouns (Iamsiu, 2014). Also, the error in adding a verb to be should be also discussed. In this type of error, the writer might hope to protect their errors in forgetting to put up a verb for making grammatically a complete sentence (subject + verb + object). Finally, it was a discussion of the error in adding the conjunction. For example, in the sentence "Although........., but........." normally the conjunction (but) should not appear. However, this was another error that was influenced by L1 interference.

\section{PEDAGOGICAL IMPLICATIONS FOR L2 LEARNING AND TEACHING}

For teachers, they will get an overall knowledge about the students' errors in writing, especially at the tertiary level (Mungungu, 2010). By familiarizing with the types of errors, it is a vital guide for designing the sequence and emphasis together with developing their teaching materials, assessment, and methods of instruction in the EFL classroom (Burt \& Kiparsky, 1978; Wu \& Garza, 2014). Moreover, the findings of this study would encourage L2 learners to pay attention to the errors that might cause miscomprehending when they do writing English as a second language, especially for academic purposes. In the other words, they can commit the same kind of errors during a certain stage of language learning by learning the errors in order to avoid them (Mungungu, 2010). Finally, the results of the present study help to develop the teaching techniques and materials in order not to make the common grammatical errors in English writing among L2 learners.

\section{CONCLUSION}

The purpose of this study was to analyze the errors made by Thai university students while writing English essays. Used as the framework for data analysis, the Surface Strategy Taxonomy (Dulay et al., 1982) was employed to explore the errors of omission, addition, misordering, and misformation. In addition, the errors which were out of the framework were also considered. The results under the framework of Surface Strategy Taxonomy showed that omission of articles was found the most frequently made, followed by the addition of the preposition, the omission of the preposition, the omission of the subject, and misformation of subject pronoun, respectively. The findings which were out of the framework of Surface Strategy Taxonomy then revealed that the error in subject-verb agreement was the highest detected error, followed by tense errors, ambiguous sentences, a direct translation from L1 to L2, misformation of object pronoun, misformation of using an adjective as the main verb, the addition of verb to be, and addition of conjunction, accordingly. The findings would also benefit for pedagogy in the way of developing both writing course and teaching material. For further study, the researchers should also conduct the qualitative method by interviewing the participants in order to get genuine data on the errors that they exactly did.

\section{ACKNOWLEDGEMENTS}

I would like to thank my colleagues at the Faculty of Management Sciences, Kasetsart University for their kindness and encouragement. Also, my gratitude goes to my beloved grandfather, Assoc. Prof. Dr. Udom Piriyasing, for his inspiration and love.

\section{REFERENCES}

[1] Al-Shujairi, Y. B. J. \& Tan, H. (2017). Grammar Errors in the Writing of Iraqi English Language Learners. International Journal of Education and Literacy Studies 5.1, 122-130.

[2] Alanazi, M. S. (2017). Assessment of Learning Difficulties (LD) in Writings of Arab Learners: A Perspective. International Journal of Education and Literacy Studies 5.3, 73-81.

[3] Anthony, L. (2005). AntConc: design and development of a freeware corpus analysis toolkit for the technical writing classroom. Paper presented at the IPCC 2005. Proceedings. International Professional Communication Conference.

[4] Bennui, P. (2016). A study of L1 intereference in the writing of Thai EFL students. Malaysia Journal of ELT Research 4.1, 72102.

[5] Boonyarattanasoontorn, P. (2017). An investigation of Thai students' English language writing difficulties and their use of writing strategies. Journal of Advanced Research in Social Sciences and Humanities 2.2, 111-118.

[6] Brown, H. (2007). Principles of language learning and teaching. New York: Pearson Longman.

[7] Brown, H. D. (2000). Principles of language learning and teaching (Vol. 4). New York: Pearson Longman.

[8] Burt, M. \& Kiparsky, C. (1972). The Gooficon: A repair manual for English. Rowley Massachusetts: Newbury House.

[9] Burt, M. \& Kiparsky, C. (1978). Global and local mistakes, in J. Schumann \& N. Stenson (Eds.). New Frontiers in second language learning. Rowley Massachusetts: Newbury House.

[10] Corder, S. P. (1967). The significance of learner's errors. IRAL-International Review of Applied Linguistics in Language Teaching 5.1-4, 161-170.

[11] Corder, S. P. (1973). The elicitation of interlanguage. In Svartvik, J. (Ed.), Errata: Papers in error analysis, 36-48. Lund: CWK Gleerup.

[12] Corder, S. P. (1981). Error analysis and interlanguage. Oxford: Oxford University Press. 
[13] Crystal, D. (1999). The Penguin dictionary of language. California: Penguin.

[14] Darasawang, P. (2007). English Language Teaching and Education in Thailand: A decade of Change. English in Southeast Asia: Varieties, Literacies and Literatures. Newcastle D. Prescott (ed.) Cambridge Scholars Publishing, 187-204.

[15] Dulay, H. B., Burt, M. \& Krashen, S. S. (1982). Language two. New York: Oxford University Press.

[16] Ellis, R. (1994). The Study of Second Language Acquisition. New York: Oxford University Press.

[17] Ellis, R. (2002). The place of grammar instruction in the second/foreign language curriculum. In E. Hinkel \& S. Fotos, New perspectives on grammar teaching in second language classrooms, 14-34. London: Routledge.

[18] Ellis, R. \& Barkhuizen, G. P. (2005). Analysing learner language. Oxford: Oxford University Press.

[19] Fareed, M., Ashraf, A. \& Bilal, M. (2016). ESL learners' writing skills: Problems, factors and suggestions. Journal of Education and Social Sciences 4.2, 81-92.

[20] Ferris, D. (2011). Treatment of error in second language student writing: Michigan: University of Michigan Press.

[21] Iamsiu, C. (2014). An analysis of grammatical errors in Srinakharinwirot University students' writing. M.A. Thesis, Srinakharinwirot University.

[22] Imaniar, F. (2018). Students' writing errors and what lies beyond them. LANGKAWI: Journal of the Association for Arabic and English 4.2, 71-83.

[23] Index, E. E. P. (2019). A Ranking of 100 Countries and Regions by English skills. Retrieved from https://www.ef.com/wwen.epi/ on April 13, 2019.

[24] James, C. (2013). Error in language learning and use: Exploring error analysis. New York: Routledge.

[25] Jobeen, A., Kazemian, B. \& Shahbaz, M. (2015). The role of error analysis in teaching and learning of second and foreign language. Education and Linguistics Research 1.2, 52-62.

[26] Khumpee, S. \& Yodkumlue, B. (2017). Grammatical errors in English essays written by Thai EFL undergraduate students. Journal of Education 11.4, 139-153.

[27] Kim, J. E. \& Yoo, I. W. (2015). A Corpus-based Study of To-Infinitive Errors in Korean College Freshmen's Writing. Journal of Asia TEFL 12.4, 37-60.

[28] Kirkpatrick, R. (2012). English education in Thailand: 2012. Asian EFL Journal 61, 24-40.

[29] Kirmizi, O. \& Karci, B. (2017). An investigation of Turkish higher education EFL learners' linguistic and lexical errors. Educational Process: International Journal 6.4, 35-54.

[30] Kongkaew, S. \& Cedar, P. (2018). An Analysis of Errors in Online English Writing made by Thai EFL Authors. International Journal of Applied Linguistics and English Literature 7.6, 86-96.

[31] Mali, Y. \& Yulia, M. (2017). Students' subject-verb agreement errors in paragraph writing class. Language and Language Teaching Journal 15.2, 21-28.

[32] Maniam, M. \& Rajagopal, P. (2016). Simple past tense errors based on surface structure taxonomy in ESL Malaysian undergraduates writing. Global journal of advanced research Journal 15.2, 21-28.

[33] Mitchell, R., Myles, F. \& Marsden, E. (2019). Second language learning theories. New York: Routledge.

[34] Mungungu, S. S. (2010). Error analysis: investigating the writing of ESL Namibian learners. M.A. Thesis, University of South Africa.

[35] Mustafa, F., Kirana, M. \& Bahri, S. (2017). Errors in EFL writing by junior high students in Indonesia. International Journal of Research Studies in Language Learning 6.1, 38-52.

[36] Namkaew, C. (2015). Error analysis in English simple past tense and past progressive tense by graduate students. M.A. Thesis, Thammasat University.

[37] Nopjirapong, R. (2011). An Analysis of Article Errors in Thai university student's Composition. M.A. Thesis, Srinakarinwirot University.

[38] Padgate, W. (2008). Beliefs and opinions about English writing of students at a Thai university. PASAA 42, 31-54.

[39] Phuket, P. R. N., \& Othman, N. B. (2015). Understanding EFL Students' Errors in Writing. Journal of Education and Practice, 6.32, 99-106.

[40] Pongpairoj, N. (2002). Thai university undergraduates' errors in English writing. Language and Linguistics 20.2, 66-99.

[41] Promsupa, P., Varasarin, P. \& Brudhiprabha, P. (2017). An analysis of grammatical errors in English writing of Thai university students. HRD Journal 8.1, 93-104.

[42] Rattanadilok Na Phuket, P. \& Bidin, S. J. (2016). Native Language Interference in Writing: A case study of Thai EFL learners. International Journal of Foreign Language Teaching and Research 4.16, 25-36.

[43] Richards, J. C., \& Schmidt, R. W. (2013). Longman dictionary of language teaching and applied linguistics. New York: Routledge.

[44] Sajid, M. \& Siddiqui, J. A. (2015). Lack of academic writing skills in English language at higher education level in Pakistan: causes, effects and remedies. International Journal of Language and Linguistics 2.4, 174-186.

[45] Selinker, L., \& Gass, S. M. (2008). Second language acquisition. New York: Routledge.

[46] Sermsook, K., Liamnimit, J. \& Pochakorn, R. (2017). An Analysis of Errors in Written English Sentences: A Case Study of Thai EFL Students. English Language Teaching 10.3, 101-110.

[47] Settanan, M. J. (2016). An error analysis of written English email of senior cabin brew: A case study at a Thai airline company. M.A. Thesis, Thammasat University.

[48] Sompong, M. (2013). Error analysis. Thammasat Review, 16.2, 109-127.

[49] Suvarnamani, S. (2017). A study of grammatical and lexical errors in descriptive writing of first year arts students at Silpakorn University. Humanities, Arts and Social Sciences Studies 17.2, 239-264.

[50] Suzanne, N. (2017). An analysis of preposition errors: The case of in, on, and at. Lingua Didaktika: Jurnal Bahasa dan Pembelajaran Bahasa, 11.1, 13-21.

[51] Thumawongsa, N. (2018). L1 Transfer on Thai EFL Learners' Utilization of Prepositions: a Corpus-Based Analysis. Journal of Community Development Research (Humanities and Social Sciences), 11.1, 35-47.

[52] Tuaycharoen, P. (2003). A reflection of Thai English. Language and Linguistics, 21.2, 47-65. 
[53] Turtulla, S. \& Lopar, E. B. (2018). Identification of Common EFL Errors in Writings of Kosovar Freshmen. European Journal of Language and Literature, 4.4, 31-42.

[54] Waelateh, B., Boonsuk, Y., Ambele, E. A. \& Jeharsae, F. (2019). An Analysis of the Written Errors of Thai EFL Students' Essay Writing in English. Songklanakarin Journal of Social Sciences and Humanities, 25.3, 55-82.

[55] Watcharapunyawong, S. \& Usaha, S. (2013). Thai EFL Students' Writing Errors in Different Text Types: The Interference of the First Language. English Language Teaching, 6.1, 67-78.

[56] Wu, H. \& Garza, E. V. (2014). Types and Attributes of English Writing Errors in the EFL Context—A Study of Error Analysis. Journal of Language Teaching \& Research, 5.6, 1252-1262.

[57] Zheng, C. \& Park, T. J. (2013). An analysis of errors in English writing made by Chinese and Korean university students. Theory and Practice in Language Studies, 3.8, 1342-1351.

Prathomwat Suraprajit is an assistant professor at Faculty of Management Sciences, Kasetsart University Sriracha Campus. His research interests are English language teaching and ESP. 